\title{
FACTORS MOTIVATING ACADEMIC TEACHERS TO IMPROVE THEIR TEACHING SKILLS - PILOT STUDIES
}

\author{
Iwona ZDONEK ${ }^{1 *}$, Anna MULARCZYK ${ }^{2}$ \\ ${ }^{1}$ Silesian University of Technology, Gliwice; iwona.zdonek@polsl.pl, ORCID: 0000-0002-3377-0904 \\ ${ }^{2}$ Silesian University of Technology, Gliwice; anna.mularczyk@.polsl.pl, ORCID: 0000-0002-6369-3890 \\ * Correspondence author
}

Purpose: The purpose of this paper is to develop hypotheses regarding the factors shaping the internal motivation of academic teachers to improve their teaching skills. Teaching methods and forms of communication have become the main research context.

Design/methodology/approach: The studies were based on the review of literature on motivation theory and pilot surveys. The pilot analysis was based on data visualization methods and factor analysis.

Findings: The use of modern communication methods might be correlated to age, and the use of modern teaching methods to gender. The teaching methods and forms of communication with students are influenced by factors related to the need to acquire knowledge and peer pressure.

Originality/value The paper stresses an important aspect of the work of an academic teacher which is didactic work, which is not often taken into account in scientific research. The paper attempts to examine the factors that shape the teacher's motivation to improve their working methods in this regard.

Keywords: motivational factors, internal motivation of academic teacher, teaching methods.

Category of the paper: research paper.

\section{Introduction}

Employee motivation is a very important element of human resource management (Karna, \& Knap-Stefaniuk, 2017). It also applies to human resource management at higher schools. The motivation of academic teachers significantly affects their involvement, results and productivity, and thus their achievements and the effectiveness of the entire university. Currently, a lot of attention is paid to factors that motivate various professional groups to work (Hysa, \& Grabowska, 2014), but still very little research is directed at the motivation of academic staff. Although there has been research in this field conducted by foreign (Ryan, 2014; 
Firat, 2016; Jindal-Snape, \& Snape, 2006; Maloletko, 2018) and Polish reserchers (ChrupałaPniak, \& Grabowski, 2016; Kwiek, \& Antonowicz, 2013; Szromek, \& Wolniak, 2018) but it covered the aspect of didactic work to a limited extent (Zdonek, 2018), and focused primarily on scientific work. As Machado-Taylor et al. (2016) write, work motivation of academic staff may be connected with such areas of activity as: motivation for scientific research, motivation to work in a given institution, motivation for teaching, motivation to serve the community, motivation to participate in various government organisations, motivation related to the prestige of work at the university. This paper covers issues of motivation of a researcher with regard to their didactic duties. Therefore, it does not exhaust the subject of other factors that affect the quality and effectiveness of the researcher's work, but only focuses on the narrow part related to their didactic work.

The main goal of the paper is to develop hypotheses concerning:

- the hidden factors shaping the internal motivation of academic teachers to improve their teaching skills,

- the factors affecting the teaching methods and forms of communication used.

To achieve the set goal, a review of available literature in the field of employee motivation, including academic staff, was conducted. On this basis, the initial assumptions for the structure of the questionnaire and initial questions were formulated. Then a pilot survey was conducted and a pilot analysis of the results obtained was carried out.

Paper was organised in the following way. In Part One, a review of the available literature on the motivation of researchers was conducted. Part Two presents the methodology of pilot studies. In Part Three the results of pilot studies are shown and the obtained results are discussed. The paper ends with a conclusion.

\section{Literature review}

Motivation is a very broad concept discussed in many sciences and disciplines, including psychology (Locke, \& Latham, 2002; Gómez-Miñambres, 2012), economic sciences (Kuc, \& Moczydłowska, 2009; Sekuła, 2008) or management science (de Lourdes Machado-Taylor, 2016; ). A very large number of definitions of motivation make this concept difficult to define clearly. Penc (2011, p. 243) describes motivation as a set of psychological or physiological factors triggering and organising human behaviour aimed at achieving a specific goal, a psychological mechanism regulating any behaviour following a choice. Kuc and Moczydłowska (2009, p. 77), however, defines it as a psychological mechanism that activates and organizes human behaviour aimed at achieving a set goal. 
Generally, it can be said that motivation is the driving force behind human behaviour and actions. It is often a necessary factor, one of the most important ones for increasing the efficiency of the entire organisation. Human motivation is very complicated and, therefore, it is difficult to create its one universal model or develop one universal theory. However, various motivation theories and models have appeared in the literature throughout the years. Theories most frequently cited in the literature include (Osuch, 2012):

- Content theories, which emphasise the importance of individual's needs as the basic motivational factors for action. They are associated with such names as: A. Maslow, F. Herzberg, D. McClelland and D. McGregor. According to this approach, the most important thing is to know and understand the internal factors of an individual that make him or her act in a certain way. The most popular content theories include: hierarchy of needs of A.H. Maslow (1954), the two-factor theory of the needs of F. Herzberg (1959), the theory of the three needs of McClelland et al., (1953), Theory X and Theory Y of D. McGregor (1960) and the theory of "labour motivation" of A.A. Litwinyuk (1997).

- Process theories, which were created within the school of social systems, characterised by an integrative approach to management, including motivation. Process theories determine how and by what goals individuals are motivated. They focus their attention not only on the components of the process affecting employees, but above all on understanding why employees choose a particular behaviour to achieve their goals. Therefore, the aspect of the choice of behaviour made by the employee is important here. The most popular theories in this group include: Likert's expectations value theory (1961), Adams's theory of justice (1963), Earley and Shalley's (1984) and Locke and Latham's (2002) goal setting theory.

- The theory of reinforcements, also known as the theory of behavior modification, was formulated on the basis of B.F. Skinner's theory of learning, according to whom human behaviour is affected by the effects of previous experience. One of the main views of this approach is that if an individual reacts in a certain way in a given situation and this reaction is rewarded, then the likelihood of it repeating in the same or similar circumstances increases. The following theories can be included in this group: Skinner's (1969), Hammer's (1974) and Bandura's (1977).

The most common approach to motivation identifies its two sources:

- external motivation - which means that the undertaken activity is a consequence of external coercion,

- internal motivation that results from automatically appearing stimuli that cause people to behave in a certain way or move in a certain direction.

Deci and Ryan (Deci, and Ryan, 1985), creators of the Self-Determination Theory (SDT), have the greatest contribution to understanding the mechanisms of the theory of internal and external motivation. In this theory, a person's behaviour can be motivated externally and internally, taking into account the innate needs of autonomy, competence and relations with 
others. External motivation from the lowest to the highest level of self-determination is divided into external regulations (rewards and punishments), introjection (internalisation) and identification. Internal motivation is not homogeneous either and includes internal motivation focused on knowledge, internal motivation focused on achievement and internal motivation towards stimulation of sensations. The third motivational type, complementing the theory and also occurring at the beginning of the continuum of external motivation, is amotivation or lack of motivation. Amotivation occurs when a person does not see the relationship between action and result (Deci, and Ryan, 1985). They are not externally or internally motivated and believe that their behaviour and action is caused by factors beyond their control, i.e. force majeure. In other words, amotivation is a state in which a person does not feel any need to undertake activity, which is most often due to a lack of sense of effectiveness of action and control over it. Amotivation results from the fact that a person does not value a given activity, does not feel competent to perform it, or believes that an activity will not lead them to their desired goals.

Deci and Ryan (2008) have also proved in their research that controlling individual motivation by typically financial factors as well as a system of rewards and punishments destroys internal motivation. In this way, external motivation becomes a short-term impact, because individuals need a strong turn towards competence, autonomy and purpose. First of all, Deci and Ryan (2008) state that the key process supporting the optimal functioning of individuals is their natural pursuit of improvement and development, manifested in satisfying the universal needs: social relations, competence and autonomy. As a consequence, employees may experience the feeling of pleasure and satisfaction (Chrupała-Pniak, \& Grabowski, 2016). Based on the SDT theory, Firat (2016) investigated the motivational factors of young scientists from eight universities in Turkey. The results of this research indicate that the least important motivating factor for scientists is money, while the largest sources of motivation are first contribution to human life, then science, scientific curiosity and career. These four motivational factors can therefore be considered as the internal motivation of the scientist. Moreover, Firat (2016) examined whether the academic staff's skills in using ICT tools affect their productivity and the implementation of scientific research. It turned out that scientists who did not have high competence in the use of ICT tools more often chose money as a motivating factor. Scientists with high-quality publications (high journal ranking) and greater ICT skills saw prestige and career as motivation for research much more often than scientists from universities with low publication quality.

It can therefore be concluded that the self-determination theory SDT is a theory with great potential, of particular importance for the study of factors motivating academic staff. This paper is focused on the internal motivation of the researcher with regard to their teaching activity. Although this is not the only aspect of their work (because research is a very important part of it), being an academic teacher is related to such important issues as disseminating science and educating young generations. Factors motivating an academic teacher to make efforts to improve their teaching skills are different from those that motivate them to research work. They 
may result from the pressure to adapt to the needs of new generations and to develop new methods and means of disseminating knowledge based on modern information and communication technologies (ICT) (Hysa, \& Zdonek, 2020). It is therefore important to study the factors motivating academic teachers in this regard. This paper covers therefore the didactic aspect of an academic teacher's work.

The main focus has been put on seeking the factors that shape an academic teacher's need to improve their teaching skills. The key aspects investigated in the course of research were communication with students (especially the use of ICT tools) and the use of modern and traditional teaching methods.

\section{Methods}

\subsection{Questionnaire structure}

The questionnaire had the following structure. The first question concerned the preferred methods of communication and the next one - the preferred teaching methods. Answers regarding preferred communication methods were given on a 5-point scale, where 1 - definitely doesn't suit me, and 5 - definitely suits me. Similarly, the question about the preferred teaching methods was answered on a 5-point scale, where 1 - I don't use it at all, 5 - I use it very often. The questionnaire also included a question about identification of a given method as traditional or modern. The answers to this question were measured on a nominal scale. The questionnaire included also 8 statements regarding the recognized need for training in the field of new teaching methods (Table 1). The answers to the statements were scaled on a 5-point scale, where 1 - I strongly disagree, 5 - I strongly agree. Eventually, the questionnaire contained 18 questions (5 metric and 13 substantive).

\section{Table 1.}

Statements regarding the recognized need for further training

\begin{tabular}{|l|l|}
\hline 1 & I am eager to expand my knowledge of modern teaching methods \\
\hline 2 & I consider further training in modern teaching methods unnecessary (reversed question) \\
\hline 3 & I don't often have an opportunity to train in modern teaching methods (reversed question) \\
\hline 4 & I often attend trainings and workshops on new teaching methods \\
\hline 5 & I like to learn new methods of teaching and working with students \\
\hline 6 & $\begin{array}{l}\text { I feel coerced to expand my knowledge of modern teaching methods because these days students expect } \\
\text { different methods }\end{array}$ \\
\hline 7 & I feel pressure from my superiors to use modern teaching methods \\
\hline 8 & $\begin{array}{l}\text { I consider it necessary to use modern teaching methods and tools if I want my classes to be perceived by } \\
\text { students as interesting }\end{array}$ \\
\hline
\end{tabular}




\subsection{Description of the sample involved in the pilot study}

36 academic teachers took part in the pilot study: 16 women and 20 men. The subjects work in three provinces: mostly Śląskie (26 individuals), Dolnośląskie (6) and Lubelskie (4). They represented mainly social sciences (18 people) and engineering and technical fields (16), but also science and natural sciences (1) and humanities (1). Among the subjects, 6 teachers worked for no more than 5 years, 5: between 5 and 10 years, 7: between 10 and 15 years, 9: between 15 and 20 years, 6: between 20 and 25 years and 3: between 25 and 30 years. The respondents were also initially divided into three age groups in the questionnaire (according to the theory of generations): generation X: age 25-38, generation Y: age 39-54, and generation of Baby Boomers: age 55-65. Generation Y constituted the largest group, 23 people.

\subsection{Search for hidden variables}

In order to reveal hidden variables, factor analysis was conducted. Factor analysis (Stanisz, 2007) belongs to a group of methods that reduce dimensionality. Its purpose, apart from reducing the number of variables, is often to detect the structure or general regularities occurring between variables, to verify them, as well as to search for hidden factors with which it will be possible to describe and classify the examined objects in new spaces. The last aspect is important in relation to the described research. Generally, this method formulates systems of linear equations in the form of mathematical models. Based on the matrix of variable correlation coefficients, vectors representing measurements are extracted. Factor analysis is based on the rotation of the coordinate axes of these vectors in such a way that they can be described in a simpler way. The calculations whose results have been presented in this paper, have been mostly carried out using the Statistica package.

For factor analysis to be meaningful, the observed variables should be at least partly mutually correlated by groups, so the significance of correlations between them should be checked initially. Barlett's sphericity test can be used for this purpose. In this test, a null hypothesis is made, with no correlation between variables ${ }^{1}$, against the alternative hypothesis that there are significant correlations.

When making calculations, you must first decide on the number of factors. This decision is highly dependent on the researcher who uses the selected criterion. The literature describes such criteria as: the criterion of half, sufficient proportion, Kaiser's or Cattell's scree test. According to the half criterion, the number of extracted factors should not be greater than half the number of variables. The criterion of sufficient proportion should take into account so many factors that the sum of their variances reaches the assumed value (e.g. 70\%). In Kaiser's criterion, only those factors whose eigenvalues are greater than 1 are taken into account. In the scree

\footnotetext{
${ }^{1} \mathrm{H}_{0}: \mathrm{R}=\mathrm{I}$ (where $\mathrm{R}$ - correlation matrix, $\mathrm{I}-$ unit matrix). The test of this hypothesis is the $\mathrm{U}$ statistics expressed by the formula: $U=-\left(n-1-\frac{2 p+5}{6}\right) \sum_{i=1}^{p} \ln \lambda_{i}$ (where: $\mathrm{n}=$ number of cases, $\mathrm{p}-$ number of variables, $\lambda_{i}-\mathrm{i}$-the eigenvalue). $U$ statistics has a distribution of $\chi^{2}$ with $\mathrm{p}(\mathrm{p}-1) / 2$ degrees of freedom.
} 
criterion it is necessary to create a line graph from eigenvalues (decreasing values). The limiting factor is the factor after whose point a milder decrease can be observed to the right.

After deciding how many factors should be used for further calculations, the rotation stage follows. The following rotation methods are available in the Statistica package: varimax, quartimax, biquartimax and equartimax. They differ in the way they maximize the variance of raw factor loadings. In varimax rotation, this is done for each factor, and in quartimax for variables. The last two methods are combinations of the first two.

\subsection{Data visualisation methods}

Apart from calculations, data visualisation also played an important role in the analysis. Boxplot charts (for variables measured on a 5-point scale) were used to study the distributions of the studied variables, both created for the entire sample and for its subsets based on demographic features. The questionnaire was also equipped with a question checking the correctness of its filling, which was analysed on the basis of the interaction chart.

\section{Results and discussion}

\subsection{Communication methods}

The first question asked to academic teachers was the question of the preferred form of communication with the students. Distribution of responses for individual forms of communication is presented in Figure 1.

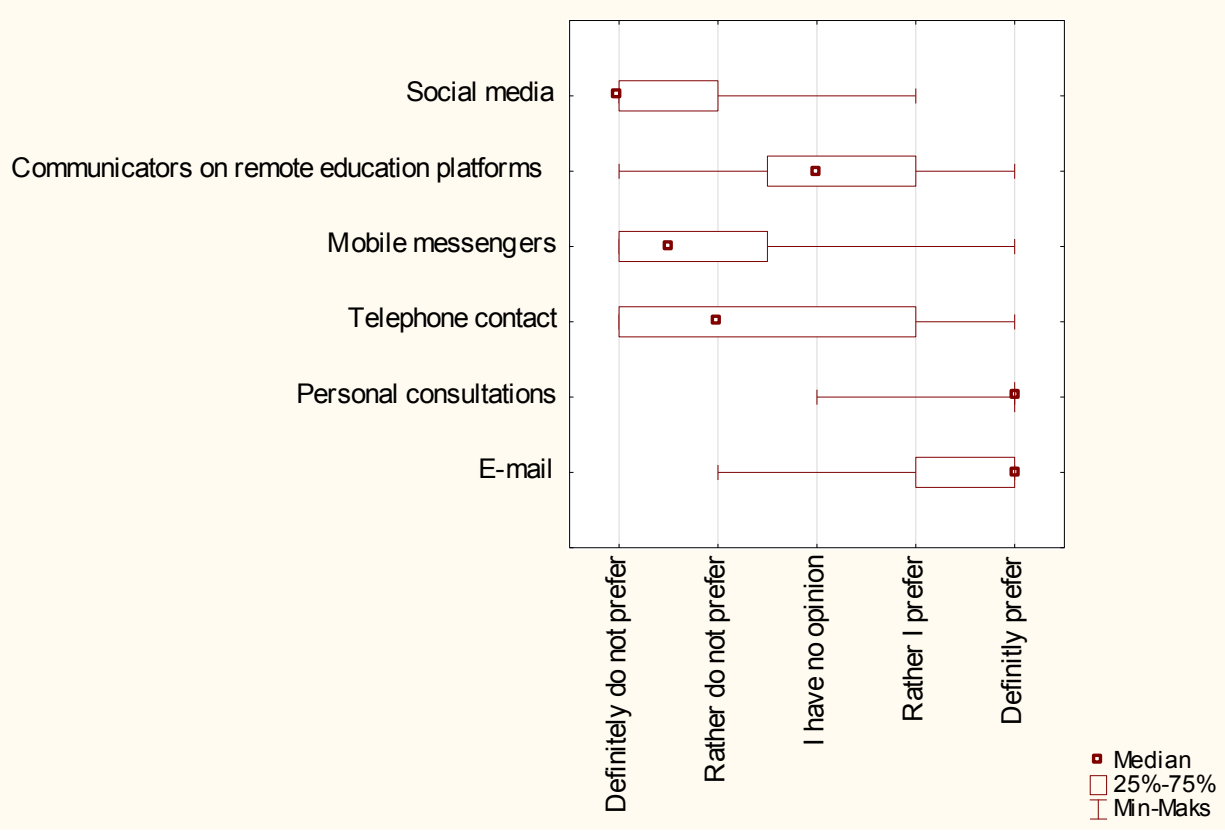

Figure 1. Preferred forms of communication with students - frame-mustache chart. 
Analysing the chart above together with the calculated descriptive statistics, it can be concluded that the most preferred form of communication are personal consultations (which have reached an average value of 4.78) and e-mail communication (with an average of 4.28). IM tools on remote education platforms enjoyed a moderate popularity (2.98), although it was in relation to this form of communication that most subjects answered "I have no opinion". The respondents did not opt for contact via social media (2.08), mobile messengers (2.25) and telephone (2.27). It can therefore be assumed that although face to face communication seems to be irreplaceable, such forms of communication as e-mail and instant messaging tools on remote education platforms may have a high preference rate among teachers. Contact via social media is currently rated as a poorly preferred form of communication. Examining the distribution and preference statistics in subsets formed on the basis of demographic features, it was found that age (analysed in the context of the X, Y and Baby Boomers generations) may be a variable that will determine the preferred form of contact, probably the biggest differences in this regard will apply to the Baby Boomers' generation (Figure 2).
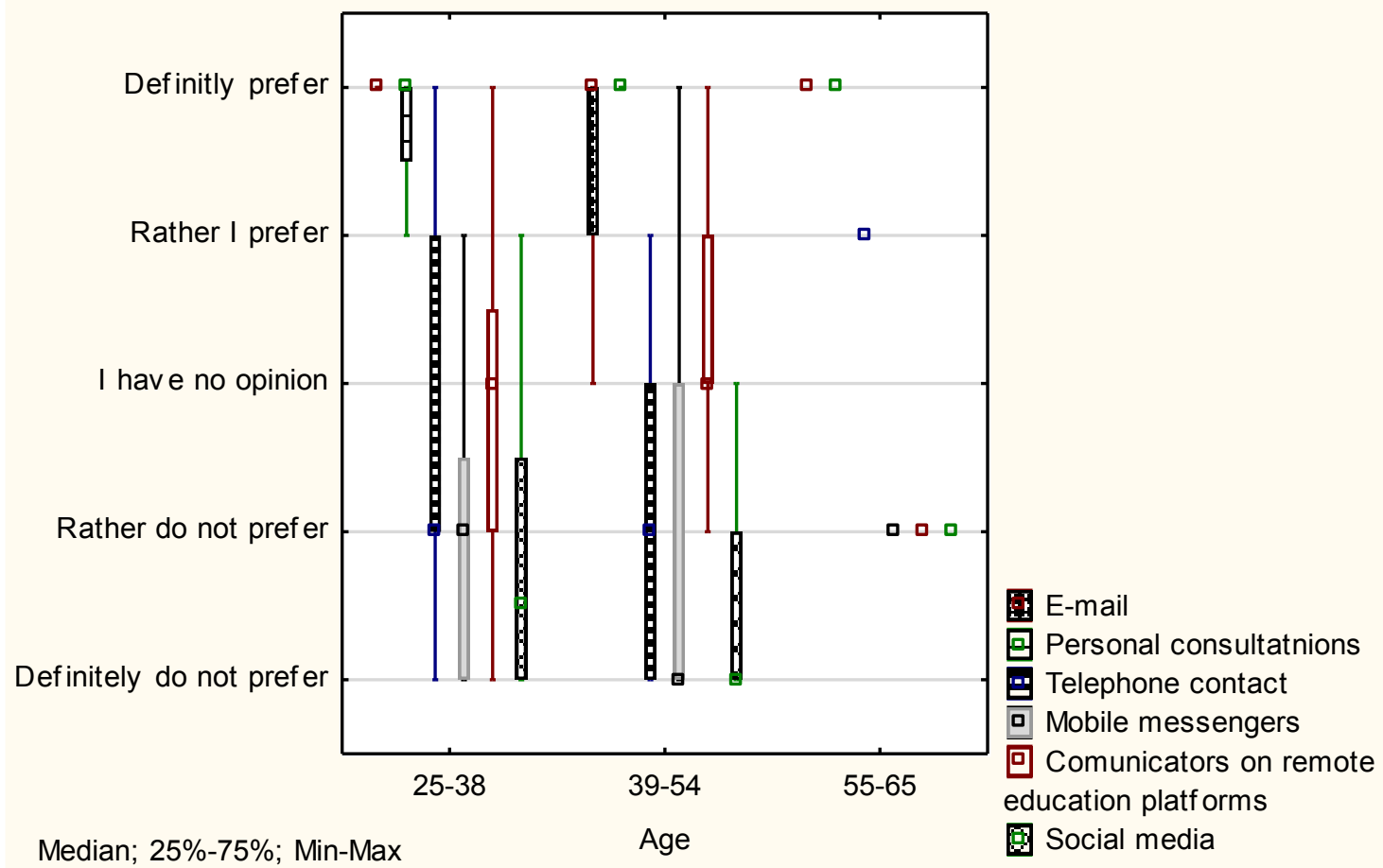

Figure 2. Preferred forms of communication with students depending on age.

A similar analysis should be made should be made with regard to the gender of the respondents (Figure 3). On both figures, slight differences are seen in the perception of the examined forms of communication in individual groups. However, in order to determine if they can be generalized to the entire population, studies would have to be conducted on a larger sample. 


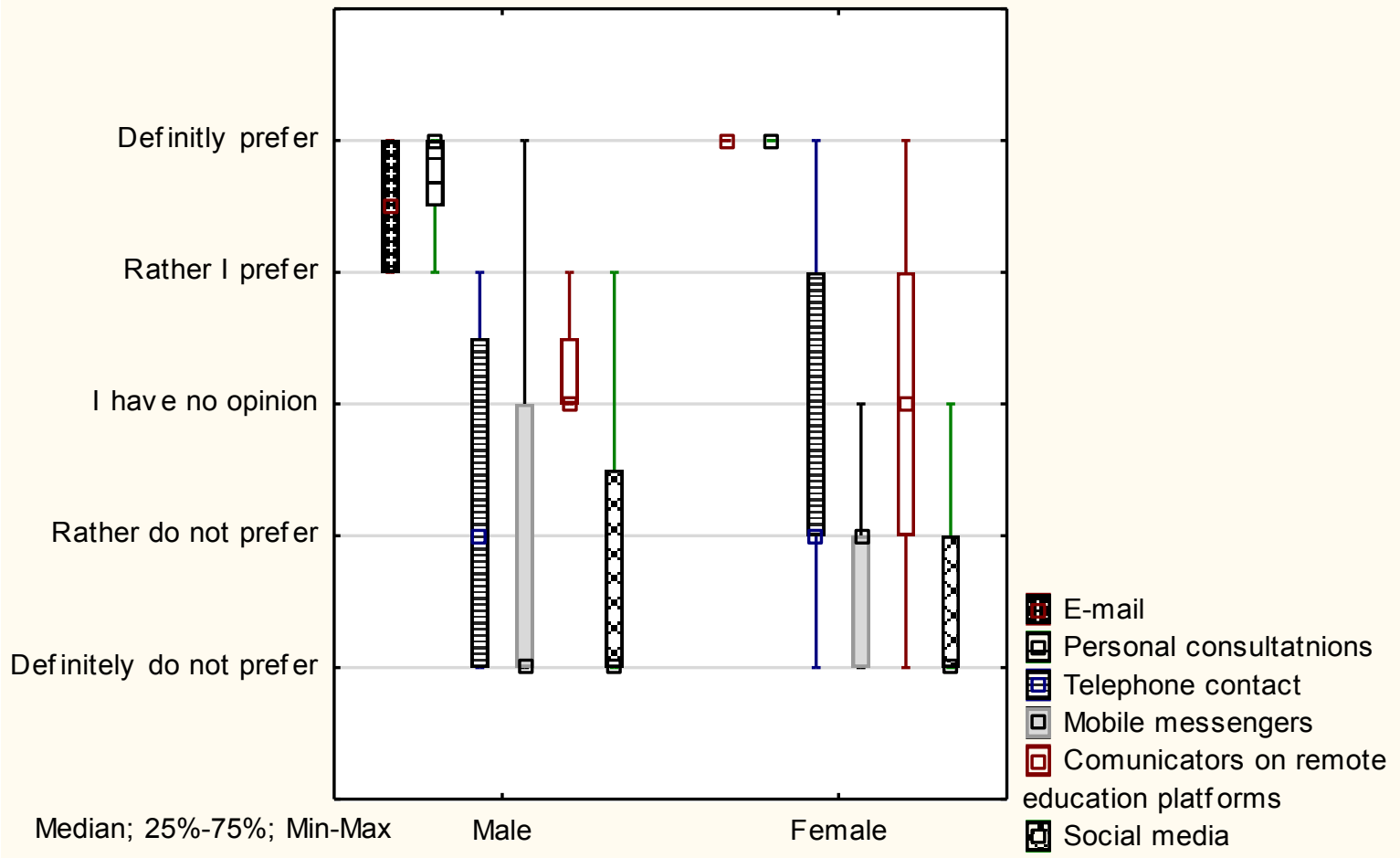

Figure 3. Preferred forms of communication with students depending on gender.

\subsection{Teaching methods}

Subsequently, the questions about preferred teaching methods and tools used in the teaching process were asked (Fig. 2). Here, too, traditional forms prevailed, such as: lecture (with an average score of 4.53), doing exercises (4.42), group work (4.22), and discussion (3.64). At least half of the respondents have never used such methods as: student portfolio (1.31), learning by teaching (2.28), iconographic poster (1.61), metaplan (1.36), guiding text method (1.83), Jigsaw method (1.11), staging / roleplaying (1.56) or flipped classroom (1.69). 


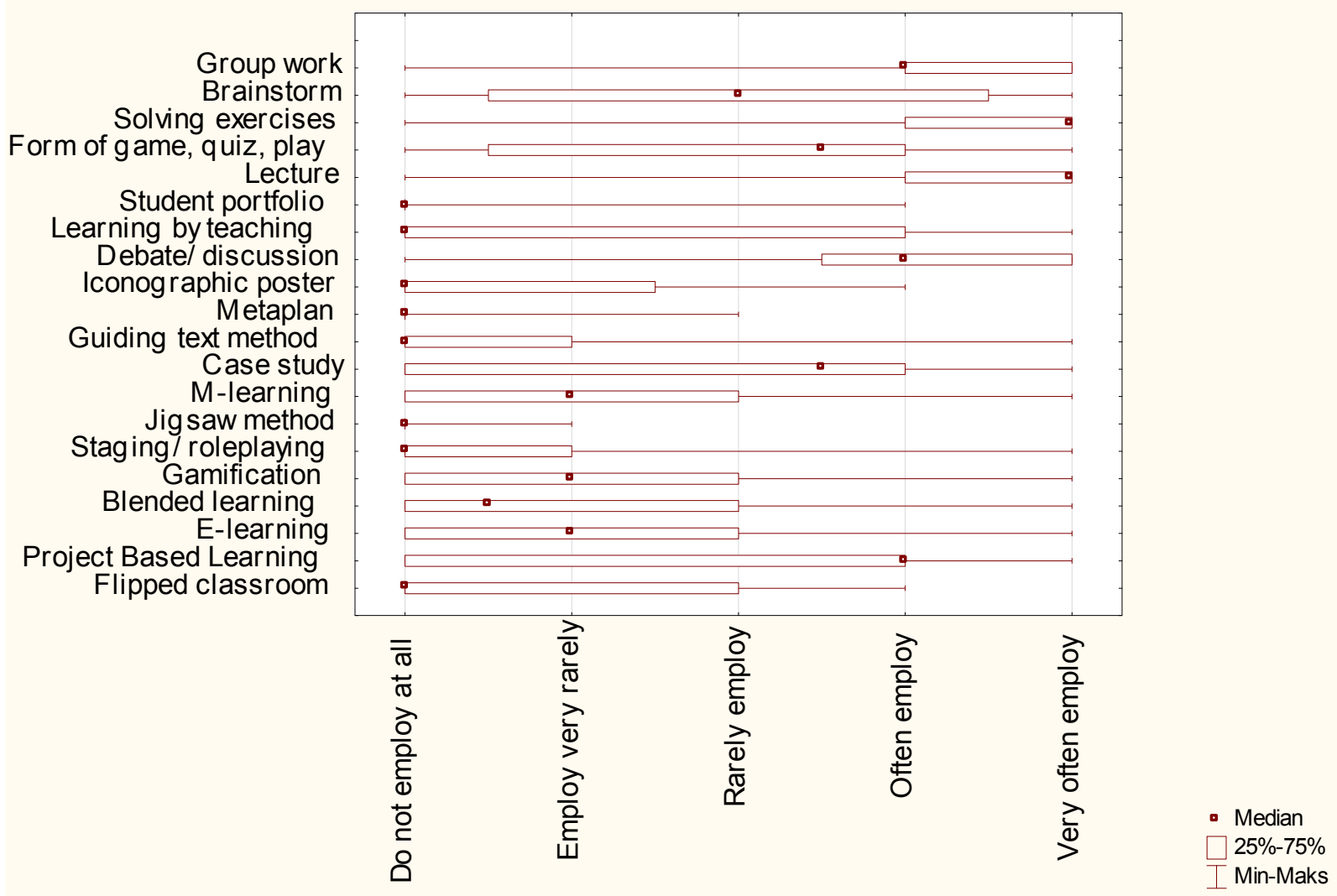

Figure 4. The preferred teaching methods and tools used in the teaching process.

The frequency of use of specific teaching methods was also analysed, classifying these methods into: modern, traditional, I don't know. Preliminary analyses lead to the conclusion that the group of methods most often used are traditional methods, and the group of methods most rarely used are methods perceived as modern or those which teachers cannot label neither as traditional nor modern. It has also been observed that the frequency of using some teaching methods may depend on gender (Figure 5). 


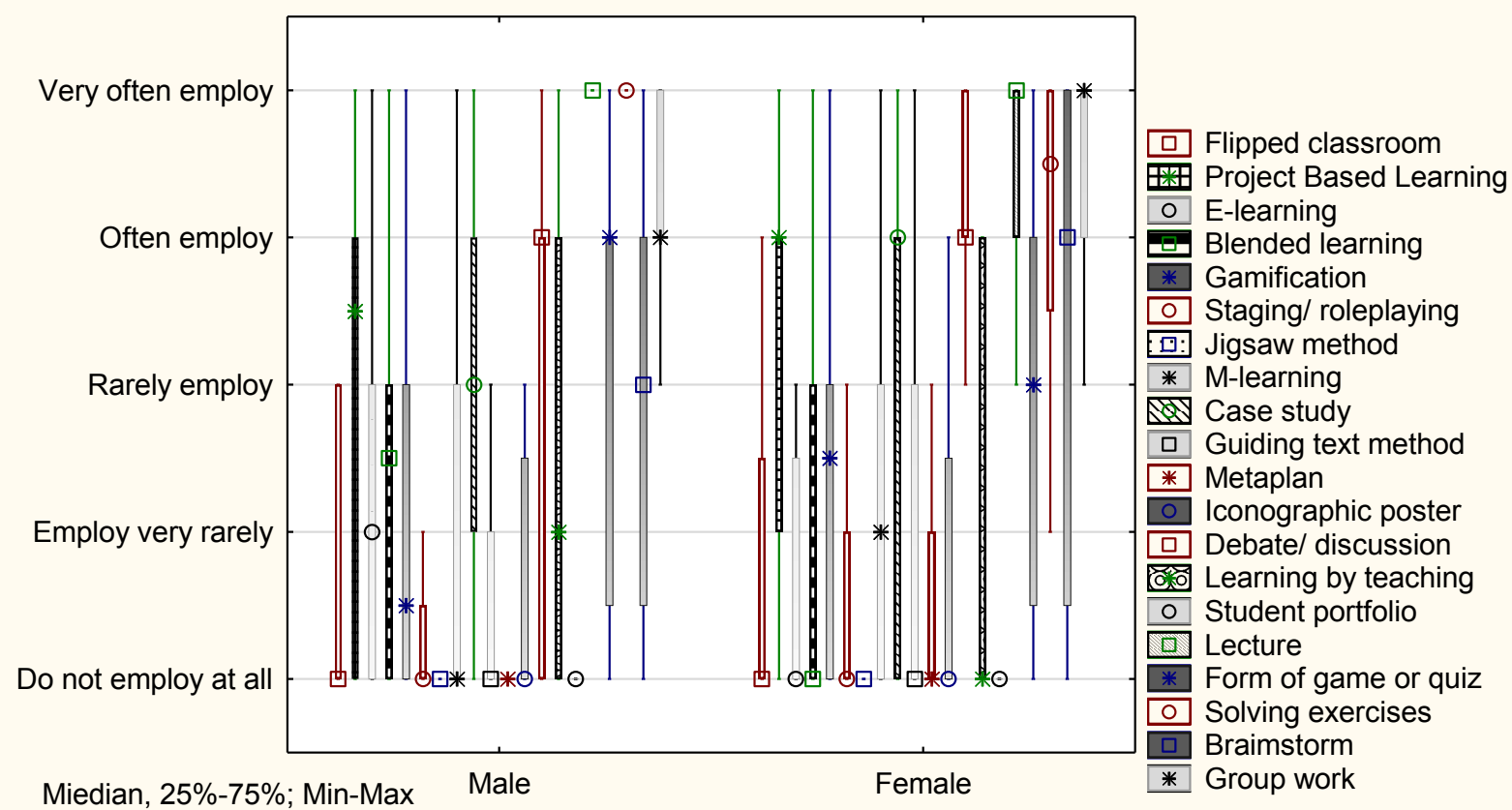

Figure 5. The preferred teaching methods and tools used in the teaching process and gender.

\subsection{Search for hidden variables}

In order to search for hidden variables in the area of the recognized need for training, the results of pilot studies were visualized. They are presented in

Figure 6.

1. I am eager to expand my knowledge of modern teaching methods

2. I consider further training in modern teaching methods unnecessary (reversed question)

3. I don't often have an opportunity to train in modern teaching methods (reversed question)

4. I often attend trainings and workshops on new teaching methods

5. I like to learn new methods of teaching and working with students

6. I feel coerced to expand my knowledge of modern teaching methods because these days students expect different methods

7. I feel pressure from my superiors to use modern teaching methods

8. I consider it necessary to use modern teaching methods and tools if I want my classes to be perceived by students as interesting

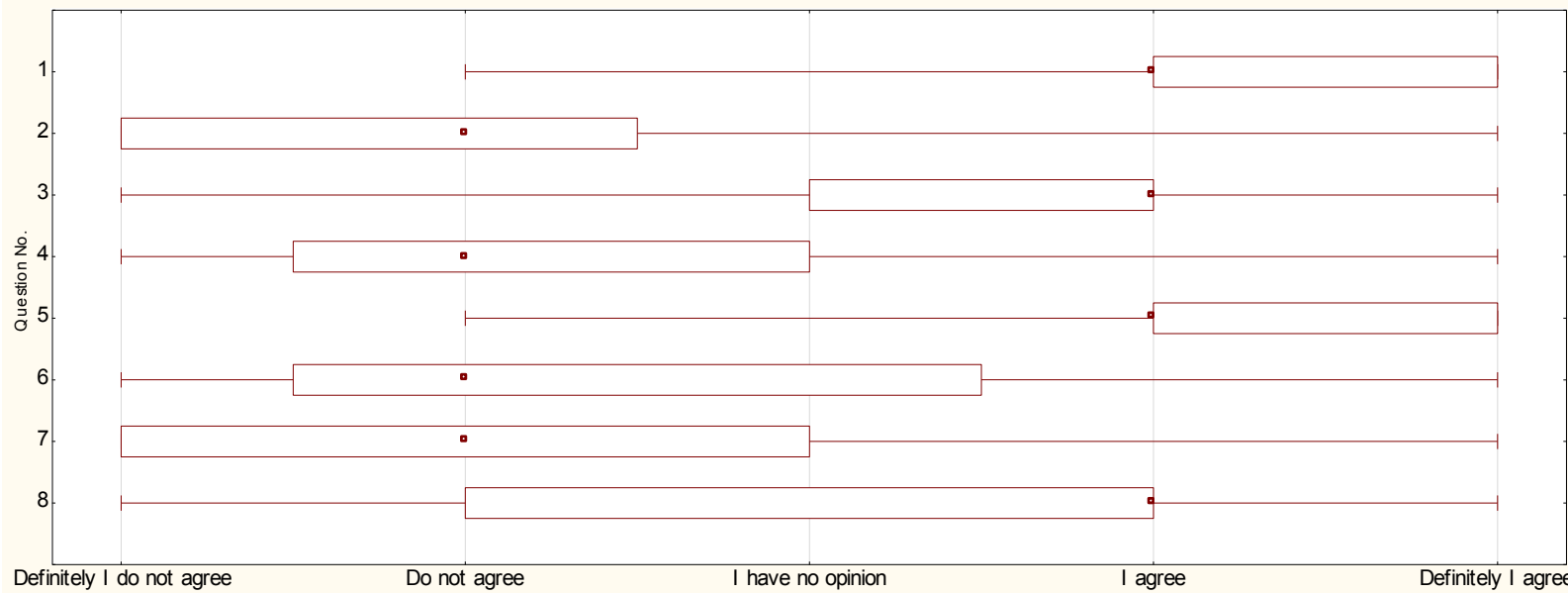

Figure 6. Distribution of answers in terms of variables describing the need for training. 
First, it was checked whether there were dependencies between variables. This can be seen by looking at the correlation matrix (Table 2).

Table 2.

Variable correlation coefficients

\begin{tabular}{|c|c|c|c|c|c|c|c|c|}
\hline Variable & 1 & 2 & 3 & 4 & 5 & 6 & 7 & 8 \\
\hline 1 & 1 & -0.339 & -0.337 & 0.516 & 0.698 & 0.238 & 0.327 & 0.590 \\
\hline 2 & -0.339 & 1 & 0.040 & 0.158 & -0.266 & -0.118 & 0.084 & -0.476 \\
\hline 3 & -0.337 & 0.040 & 1 & -0.656 & -0.314 & 0.012 & 0.141 & -0.233 \\
\hline 4 & 0.516 & 0.158 & -0.656 & 1 & 0.523 & 0.212 & 0.182 & 0.291 \\
\hline 5 & 0.698 & -0.266 & -0.314 & 0.523 & 1 & 0.092 & 0.176 & 0.461 \\
\hline 6 & 0.238 & -0.118 & 0.012 & 0.212 & 0.092 & 1 & 0.310 & 0.308 \\
\hline 7 & 0.327 & 0.084 & 0.141 & 0.182 & 0.176 & 0.310 & 1 & 0.131 \\
\hline 8 & 0.590 & -0.476 & -0.233 & 0.291 & 0.461 & 0.308 & 0.131 & 1 \\
\hline
\end{tabular}

Barlett's test was also carried out, which confirmed the existence of significant correlations between variables ${ }^{2}$.

When searching for hidden variables, two criteria were initially taken into account when deciding on the number of factors (potential hidden variables): Cattell's scree and Kaiser's. The table with eigenvalues (Table 3) and the scree chart (Figure 7) were analysed.

Table 3.

Eigenvalues

\begin{tabular}{|c|c|c|c|c|}
\hline Value & Eigenvalue & \% of total variance & Cumulative eigenvalue & Cumulative \% \\
\hline 1 & 3.117880 & 38.97350 & 3.117880 & 38.9735 \\
\hline 2 & 1.454111 & 18.17638 & 4.571990 & 57.1499 \\
\hline 3 & 1.300441 & 16.25551 & 5.872431 & 73.4054 \\
\hline 4 & 0.819707 & 10.24634 & 6.692138 & 83.6517 \\
\hline 5 & 0.464970 & 5.81213 & 7.157109 & 89.4639 \\
\hline 6 & 0.410120 & 5.12650 & 7.567229 & 94.5904 \\
\hline 7 & 0.248209 & 3.10262 & 7.815439 & 97.6930 \\
\hline 8 & 0.184561 & 2.30702 & 8.000000 & 100.0000 \\
\hline
\end{tabular}

\footnotetext{
${ }^{2}$ Check statistics: $U=99.7$ was obtained and critical value: $\chi^{2}=41.3$ (for $\alpha=0.05$ ).
} 


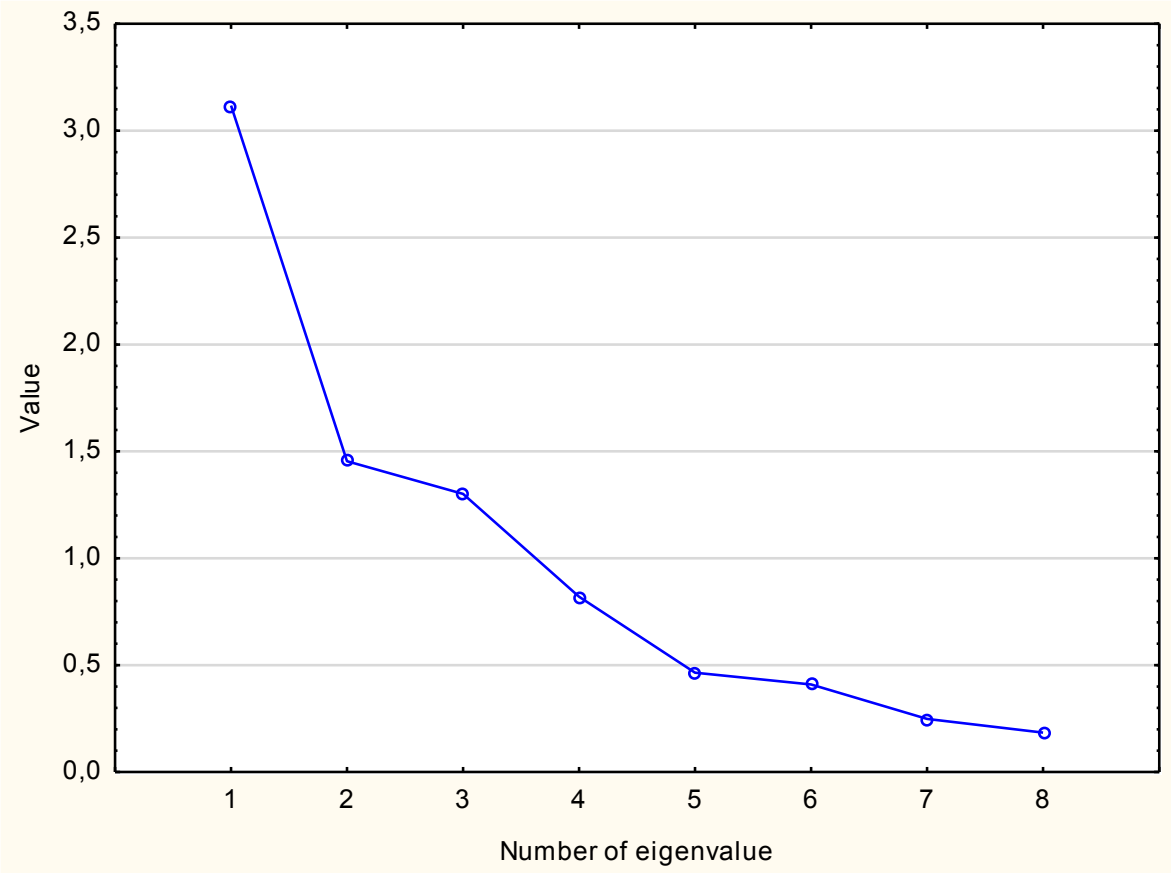

Figure 7. Scree plot.

The scree plot was initially analysed. The figure shows that the point at which the decrease in eigenvalues stabilises can be the point for the fifth value. So five factors should be selected - then they would explain over $89 \%$ of the total variance. According to Kaiser's criterion, however, three factors should be selected that explain over $73 \%$ of the total variance. Both options were explored. For substantive reasons, three factor were eventually chosen. Then rotations were made with available methods - equamax rotation gave the best results in terms of interpretation. The following table presents factor loadings determined initially without rotation and after applying rotation (Table 4). Significant values are shown in bold. 
Table 4.

Factor loadings before and after rotation

\begin{tabular}{|c|c|c|c|c|c|c|c|}
\hline \multicolumn{2}{|c|}{ Variable } & \multicolumn{2}{c|}{$\begin{array}{c}\text { Factor loadings } \\
\text { (without rotation) }\end{array}$} & \multicolumn{3}{c|}{$\begin{array}{c}\text { Factor loadings } \\
\text { (Equamax sur rotation) }\end{array}$} \\
\hline No. & Description & $\begin{array}{c}\text { Factor } \\
1\end{array}$ & $\begin{array}{c}\text { Factor } \\
2\end{array}$ & $\begin{array}{c}\text { Factor } \\
3\end{array}$ & $\begin{array}{c}\text { Factor } \\
\mathbf{1}\end{array}$ & $\begin{array}{c}\text { Factor } \\
\mathbf{2}\end{array}$ & $\begin{array}{c}\text { Factor } \\
\mathbf{3}\end{array}$ \\
\hline 1. & $\begin{array}{c}\text { I am eager to expand my knowledge } \\
\text { of modern teaching methods }\end{array}$ & -0.877 & -0.102 & 0.009 & -0.552 & $\mathbf{0 . 6 0 8}$ & 0.322 \\
\hline 2. & $\begin{array}{c}\text { I consider further training in modern } \\
\text { teaching methods unnecessary }\end{array}$ & 0.370 & 0.604 & 0.580 & $\mathbf{0 . 8 9 8}$ & 0.120 & 0.131 \\
\hline 3. & $\begin{array}{c}\text { I don't often have an opportunity to } \\
\text { train in modern teaching methods }\end{array}$ & 0.544 & -0.642 & 0.241 & 0.014 & $\mathbf{- 0 . 8 2 1}$ & 0.303 \\
\hline 4. & $\begin{array}{c}\text { I often attend trainings and } \\
\text { workshops on new teaching methods }\end{array}$ & -0.715 & 0.570 & 0.215 & 0.079 & $\mathbf{0 . 9 2 0}$ & 0.171 \\
\hline 5. & $\begin{array}{c}\text { I like to learn new methods of } \\
\text { teaching and working with students }\end{array}$ & -0.794 & 0.051 & -0.100 & -0.464 & $\mathbf{0 . 6 3 9}$ & 0.140 \\
\hline 6. & $\begin{array}{c}\text { I feel coerced to expand my } \\
\text { knowledge of modern teaching } \\
\text { methods because these days students } \\
\text { expect different methods }\end{array}$ & -0.374 & -0.376 & 0.479 & -0.205 & 0.062 & $\mathbf{0 . 6 8 2}$ \\
\hline 7. & $\begin{array}{c}\text { I feel pressure from my superiors to } \\
\text { use modern teaching methods }\end{array}$ & -0.312 & -0.272 & 0.760 & 0.042 & 0.089 & $\mathbf{0 . 8 5 9}$ \\
\hline 8. & $\begin{array}{c}\text { I consider it necessary to use modern } \\
\text { teaching methods and tools if I want } \\
\text { my classes to be perceived by } \\
\text { students as interesting }\end{array}$ & -0.733 & -0.353 & -0.209 & $\mathbf{- 0 . 7 4 7}$ & 0.330 & 0.195 \\
\hline
\end{tabular}

The above results can be interpreted as the division of the studied variables into three hidden variables (Table 5).

Table 5.

Mapping variables to factors (hidden variables)

\begin{tabular}{|c|c|c|}
\hline $\begin{array}{c}\text { Factor } 1 \\
\text { Training - as a need/higher } \\
\text { necessity (fact) }\end{array}$ & $\begin{array}{c}\text { Factor } 2 \\
\text { Training }- \text { as broadening one's } \\
\text { interests (desire to acquire } \\
\text { knowledge) }\end{array}$ & $\begin{array}{c}\text { Factor } 3 \\
\text { Peer pressure (coercion, } \\
\text { requirement) }\end{array}$ \\
\hline $\begin{array}{l}\text { 2. I consider further training in } \\
\text { modern teaching methods } \\
\text { unnecessary (reversed question) } \\
\text { 8. I consider it necessary to use } \\
\text { modern teaching methods and } \\
\text { tools if I want my classes to be } \\
\text { perceived by students as } \\
\text { interesting }\end{array}$ & $\begin{array}{l}\text { 1. I am eager to expand my } \\
\text { knowledge of modern teaching } \\
\text { methods } \\
\text { 3. I don't often have an } \\
\text { opportunity to train in modern } \\
\text { teaching methods (reversed } \\
\text { question) } \\
\text { 4. I often attend trainings and } \\
\text { workshops on new teaching } \\
\text { methods } \\
5 . \text { I like to learn new methods of } \\
\text { teaching and working with } \\
\text { students }\end{array}$ & $\begin{array}{l}\text { 6. I feel coerced to expand my } \\
\text { knowledge of modern teaching } \\
\text { methods because these days } \\
\text { students expect different methods } \\
\text { 7. I feel pressure from my } \\
\text { superiors to use modern teaching } \\
\text { methods }\end{array}$ \\
\hline
\end{tabular}

The first hidden variable represents the importance of the need for further training recognised by teachers. The questions included in this hidden variable concern the assessment of the importance of the need for training in teaching skills. It should be noted that the first hidden variable includes one reversed question - hence the minus for some factor loadings. 
The second hidden variable includes questions checking how much pleasure the responding teacher derives from acquiring knowledge about modern teaching methods. This variable also includes a reversed question (3), whose purpose is to check the correctness of completing the questionnaire, in relation to the results obtained in question 4. The third hidden variable concerns the pressure that the teacher feels from their environment in connection with the need to improve their teaching skills. Analysing the results of factor analysis, it can be seen that both the first hidden variable and the second hidden variable are associated with the SDT theory of motivation (Deci, and Ryan, 2008), mainly in terms of the need for competence. The third hidden variable can also be placed in the SDT theory, this time in the context of a need for relationships with others. However, due to the fact that the investigated methods of communication is strongly related to ICT technologies, one can also see references to the Unified Theory of Acceptance and Use of Technology (UTAUT) (Venkatesh et al., 2003) and particularly to the variable known as social impact. Therefore, it seems reasonable to consider the studied methods of communication with students also in the context of this theory.

Analysing the answers of the surveyed group, it can also be seen that individuals who were more willing to use IM tools on remote education platforms mostly agreed with sentences such as "I like learning new teaching methods...". Therefore, a hypothesis can be formulated that the factor "willingness to acquire knowledge" will positively affect the use of new methods of communication.

\subsection{Verification of correctness of completing the questionnaire}

To verify the correctness of completing the questionnaire, the answers to the verification question, question 3 (in relation to question 4), were analysed: "I don't often have the opportunity to train in modern teaching methods" and "I often participate in trainings and workshops on new teaching methods." The results are shown in interaction chart (Figure 8). 
Interaction graph: I don't have frequent opportunities to train in modern teaching methods $\mathrm{xI}$ often use trainings and workshops on new teaching methods

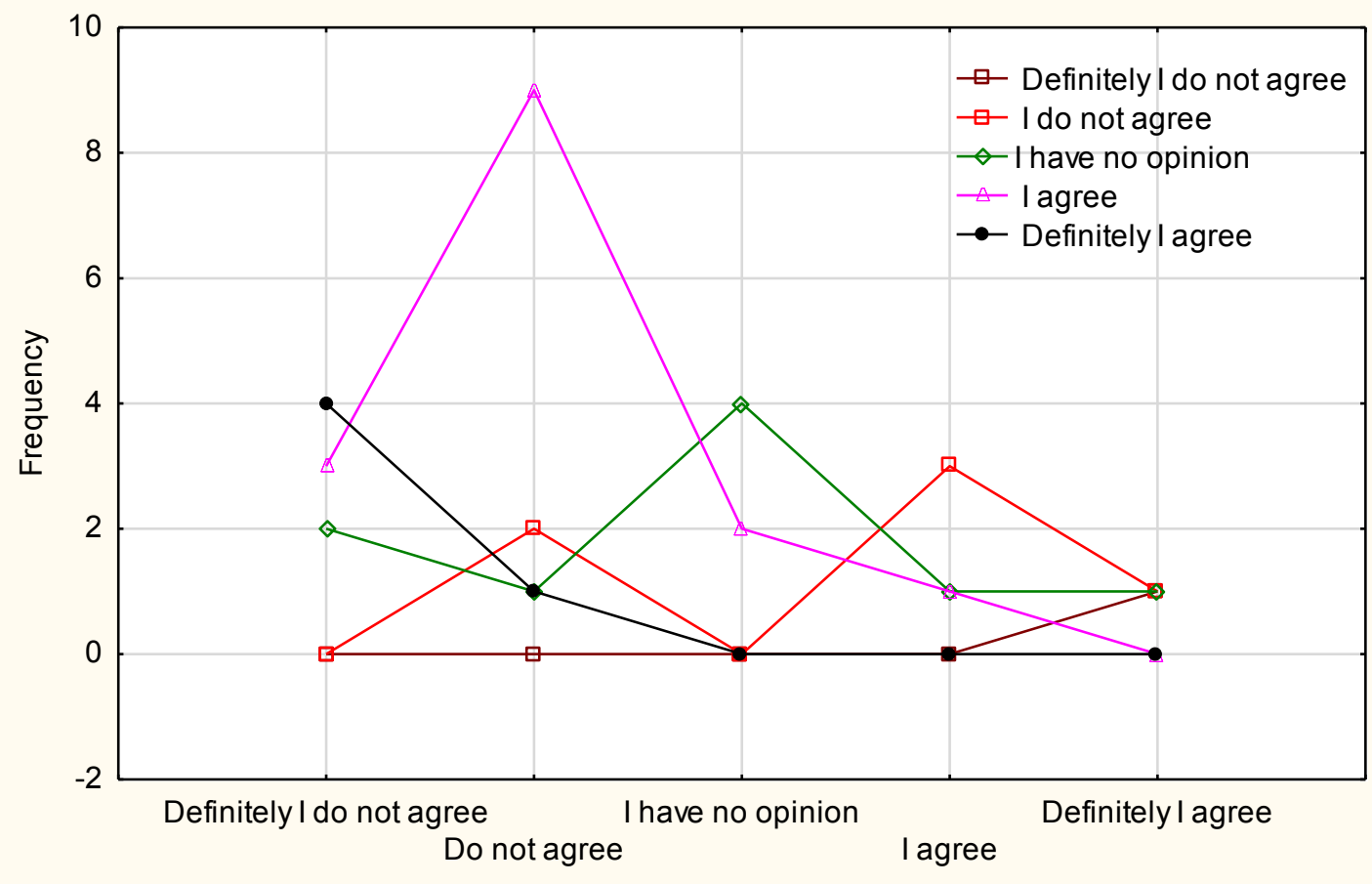

I often use trainings and workshops on new teaching methods

Figure 8. Interaction chart between question 3 and 4.

It can be seen that as the degree of agreement with the statement presented in the first question increases, the degree of agreement with the opposite question decreases. The correlation coefficient between these questions also indicates the existence of a significant negative correlation (Table 2). So the question fulfilled its role.

\section{Conclusion}

Personal consultations and e-mail communication turned out to be the most preferred form of communication chosen by academic teachers. IM tools on remote education platforms are usually preferred by teachers who are eager to use these e-learning platforms in their work with students. Social media were the least preferred form of contact with students, although here significant differences were noticed depending on age. Taking into account that there are more and more younger generation students, for whom this form of communication is the preferred way of contact, this form of communication is likely to increase in the future.

The conducted analysis also shows that traditional teaching methods and tools are used the most often in the teaching process. These include traditional forms such as lectures, doing exercises, group work and discussion. At least half of the respondents have never used such methods as: student portfolio, learning by teaching, iconographic poster, metaplan, guiding text 
method, Jigsaw method, staging/roleplaying or flipped classroom. Perhaps in further proper research the number of these methods should be limited. Especially that teachers did not know to which category, modern or traditional, to assign a specific method.

Preliminary analysis of statistics indicates that the factor "willingness to acquire knowledge" positively influenced the use of new communication methods by teachers in the study group. Therefore, the question arises how all the factors identified can affect the communication methods or teaching methods used, and whether such relationships will apply on a larger scale.

Given the results of analysis of the pilot sample studied, the authors feel the need to explore this subject. The correlations, which cannot be generalised yet to a wider population, are interesting enough to be further verified. Conducting similar research on a larger scale will systematise this knowledge. It is particularly important to make up for the quantitative differences in individual age groups - paying attention to the oldest group of respondents, whose percentage share should definitely be higher than in the pilot study.

Further research should be designed to help verify the following hypotheses:

1. Forms of communication based on modern ICT technologies depend on age.

2. Preferred teaching methods depend on gender.

3. The desire to acquire knowledge positively affects the use of modern ICT methods in communication with students.

4. Student pressure is an important factor in determining the frequency of using new communication methods.

5. Student pressure is an important factor in determining the frequency of using new teaching methods.

The conducted factor analysis helped identify three hidden variables, one of which could be developed in the direction outlined by the Unified Theory of Acceptance and Use of Technology. Therefore, in a study conducted on a larger sample, the authors intend to further expand the questionnaire with questions included in the scale developed on the basis of this theory.

\section{References}

1. Adams, J.S. (1963). Toward an understanding of inequality. The Journal of Abnormal and Social Psychology, vol. 67(5), 422-436.

2. Bandura, A. (1977). Social Learning Theory. Prentice Hall: Englewood Cliffs.

3. Chrupała-Pniak, M., Grabowski, D. (2016). Skala motywacji zewnętrznej i wewnętrznej do pracy (WEIMS-PL). Wstępna charakterystyka psychometryczna polskiej wersji kwestionariusza Work Extrinsic and Inrinsic Motivation Scale. Psychologia Spoleczna, Tom 11, Numer 3(38), Doi: 10.7366/1896180020163808, 339-355, ISSN 1896-1800. 
4. de Lourdes Machado-Taylor, M., Meira Soares, V., Brites, R., Brites Ferreira, J., Farhangmehr, M., Gouveia, O.M. R., \& Peterson, M. (2016). Academic job satisfaction and motivation: findings from a nationwide study in Portuguese higher education. Studies in Higher Education, 41(3), 541-559.

5. Deci, E.L., Ryan, R.M. (1985). Intrinsic motivation and self-determination in human behavior. New York: Plenum Press.

6. Deci, E.L., Ryan, R.M. (2008). Self-Determination Theory: A Macrotheory of Human Motivation, Development, and Health. Canadian Psychology, 49(3), 182-185.

7. Earley, Ch., Shalley, Ch. (1984). New Perspectives on Goals and Performance: Merging Motivation and Cognition. In: G. Ferris, K. Rowland (eds.), Research in Personal and Human Resources Management (pp. 121-126). Greenwich: JAI Press.

8. Firat, M. (2016). Examination of scientific research motivation and methodological paradigms of ICT oriented young education researchers. Education and Science, Vol. 41, Iss. 187, 221-237, Doi: 10.15390/EB.2016.4480.

9. Gómez-Miñambres, J. (2012) Motivation through goal setting. Journal of Economic Psychology Vol. 33, Iss. 6, 1223-1239. https://doi.org/10.1016/j.joep.2012.08.010.

10. Hammer, W.C. (1979). Reinforcement Theory and Contingency Management in Organizational Settings. In: R.M. Steers, L.W. Porter (eds.), Motivation and Work Behaviour. McGraw-Hill.

11. Herzberg (1968). One more time: how do you motivate employees? Harvard Business Review, Vol. 46, Iss. 1, 53-62.

12. Hysa, B., Grabowska, B. (2014). System motywacji pracowników administracji publicznej na podstawie wybranej jednostki ZUS. Zeszyty Naukowe Politechniki Śląskiej. Organizacja $i$ zarzadzanie, $N r$ 74, 325-342.

13. Hysa, B., Zdonek, I. (2020). Influence of generational changes on the development of teaching methods in the field of teaching information and communication technologies. Scientific Papers of the Silesian University of Technology, Organisation and Management Series, No. 144. Silesian University of Technology Publishing House, 183-193.

14. Jindal-Snape, Snape (2006). Motivation of scientists in a government research institute: scientists' perceptions and the role of management. Management Decision, Vol. 44, Iss. 10, 1325-1343.

15. Karna, W., Knap-Stefaniuk, A. (2017). Motywowanie pracowników jako wyzwanie w zarządzaniu zasobami ludzkimi. Studia $i$ Prace WNEIZ US, Nr 48/2, 161-171. Doi: 10.18276/sip.2017.48/2-14.

16. Kopertyńska, M.W. (2008). Motywowanie pracowników. Teoria i praktyka. Warszawa: Placet.

17. Kuc, B., Moczydłowska, J. (2009). Zachowania organizacyjne. Warszawa.

18. Kusy, M. (2010) Opracowanie wyników badań ankietowych w programie Statistica. https://statsoft.pl/czytelnia.html. 
19. Kwiek, M., Antonowicz, D. (2013) Academic work, working conditions and job satisfaction, in The Work Situation of the Academic Profession in Europe: Findings of a Survey in Twelve Countries, The Changing Academic Profession in International Comparative Perspective. Teichler U. and Höhle E.A. (eds.), Springer Science+Business Media Dordrecht, 37-54, Springer, Dordrecht, Doi 10.1007/978-94-007-5977-0_3.

20. Likert, R. (1961). New Patterns of Management. New York: McGraw-Hill.

21. Likert, R. The Human Organization: Its Management and Value. New York: McGraw-Hill. 22. Litvinyuk, A.A. (1997). Motivational complexes of work in the management system (on the example of retail businesses), the doctoral dissertation.

23. Locke, E.A., \& Latham, G.P. (2002). Building a practically useful theory of goal setting and task motivation: A 35-year odyssey. American Psychologist, 57, 705-717, Doi:10.1037/0003-066X.57.9.705.

24. Machado-Taylor, M.L., Soares, V.M., Brites, R., Ferreira, J.B., Farhangmehr, M., Gouveia, O., \& Peterson, M. (2016). Academic job satisfaction and motivation: findings from a nationwide study in Portuguese higher education. Studies in Higher Education, 41(3), 541-559.

25. Maslow, A.H. (1954). Motivation and Personality. New York: Harper \& Row.

26. McClelland, D. (1961). The Achieving Society. Prinston, NJ: Van Nostrand Reinhold.

27. McGregor, D. (1960). The Human Side of Entreprise. New York: McGraw-Hill Book Comp.

28. Osuch, J. (2012). Motivation as a management factor. Acta Scientifica Academiae Ostroviensis. Sectio A, No. 1, 101-120.

29. Penc, J. (2011). Kreowanie zachowań organizacji. Warszawa: Agencja Wydawnicza Placet.

30. Ryan, J.C. (2014) The work motivation of research scientists and its effect on research performance. R\&D Management, vol. 44, iss. 4. RADMA and John Wiley \& Sons Ltd.

31. Sekuła, Z. (2008). Motywowanie do pracy, teorie i instrumenty. Warszawa: PWE.

32. Skinner, B.F. (1969). Contingencies of Reinforcement. A Theoretical Analysis. New York: Appleton-Century-Crofts.

33. Stanisz, A. (2007). Przystepny kurs statystyki z zastosowaniem STATISTICA PL na przykładach z medycyny. Tom 3. Analizy wielowymiarowe. Kraków: Wydawnictwo StatSoft, 2007.

34. Szromek, A.R., Wolniak, R. (2018). Satisfaction of scientific work among polish researchers. Gliwice: Wydawnictwo Politechniki Śląskiej.

35. Venkatesh, V., Morris, M.G., Davis, G.B., Davis, F.D. (2003). User acceptance of information technology: toward a unified view. MIS Quarterly, 27(3), 425-478.

36. Zdonek, I. (2018). Gamification in higher education - Polish experience. INTED 2018, 20 Valencia, Spain. L. Gomez Chova, A. Lopez Martinez, I. Candel Torres (ed.). IATED, 21 Academy, 5544-5548. 